\title{
免疫不全症候群と悪性腫瘍
}

一わが国の原発性免疫不全症候群症例登録より—

早川浩・小林登*·矢田純一**

Jpn. J. Clin. Immun., 8(5):265 269, 1985.

\section{Primary immunodeficiency diseases and malignancy}

-A summary of the cases reported to the All Japan Immunodeficiency Registry-

\author{
Hiroshi Hayakawa, Noboru Kobayashi* and Junichi Yata** \\ Department of Pediatrics, Mejirodai Compus of Tokyo University Hospital \\ * Research Foundation of National Children's Hospital \\ ** Department of Pediatrics, Tokyo Medical and Dental University
}

\section{【Summary】}

Among 683 patients who were registered to the-All Japan Immunodeficiency Registry up to May 5, 1985 from 1975, twenty cases were reported to have developed malignant disease (s). The incidence of malignant diseases among these reported patients was approximately $3.3 \%$, which was estimated about 500 times higher than general childhood populations. The patients with Chediak-Higashi syndrome showed the highest incidence of developing, malignant lymphoma' ( 3 in 8 cases : $37.5 \%$ ) and ataxia-telangiectasia was another immunodeficiency disease highly complicated with malignancy such as non-Hodgkin lymphoma, leukemias and cancers (7 in 51 patients : $13.7 \%$ ).

Our data seemed to show almost the same results to the reports from ICR except very low incidence of malignancy in Wiskott-Aldrich syndrome (only 1 in 45 cases: $2.2 \%$ ).

Key words : primary immunodeficiency diseases, malignancy, ataxia-telangiectasia, Chediak-Higashi syndrome, non-Hodgkin lymphoma 


\section{【要旨】}

厚生省特定疾患調査研究班「免疫不全症候群」の資料より，原発性免疫不全症候群症例のうち悪性腫瘍を合併したも のについてまとめた. さらにその結果を米国の Immunodeficiency Cancer Registry の報告と比較した.

登録例 683 例中悪性腫瘍は 20 例に報告され，全例の $2.9 \%$ に相当した. 小児例に限ると，17例であった。

Chediak-Higashi 症候群と ataxia-telangiectasia にもっとも高い頿度が認められた。後者における頻度はICRのそ れに近かったが, Wiskott-Aldrich 症候群に㧍ける頻度はわが国では低かった.

腫瘍としては，Non-Hodgkin lymphoma をはじめとするリンパ細網系のものを主とし，時に癌も認められた．これ らの免疫不全症候群では小児例についてみると，一般健康児に比べ約 500 倍の腫瘍発生率を示したものと考えられ， 高危険群であることが示された。

\section{はじめに}

原発性免疫不全症候群に悪性腫場を発生しやすいこと が注目され，ヒトの発癌機構を研究する上での重要な示 唆を与えるものと考えられている.

ここでは, わが国の原発性免疫不全症候群症 例 登 録 （厚生省特定疾患調查研究「免疫不全症候群】）に報告さ れた症例について悪性腫瘍を合併したものについてまと め, 米国の Immunodeficiency Cancer Registry (ICR)
の成績と比べてその実態を示す.

\section{I. 成 精}

昭和 60 年 5 月 5 日現在登録された原発性免疫不全症 候群の症例恃，表 1 に示すごとく，男 489 例女 194 例合 計 683 例であった. このうち, 初診時 16 歳以上の成人 例は 66 例 $(9.7 \%)$ で汪かはすべて小児例である.

これらの中で，悪性腫瘍を合併したと報告されたもの は，表 2 に示す合計 22 例であった. このうち，?を付

表 1 The Total Number of Registered Cases with Primary Immunodeficiency Syndrome in Japan

(May 1985)

\begin{tabular}{|c|c|c|c|c|c|}
\hline Diseases & Male & Female & Total & $\begin{array}{l}\text { Adult } \\
\text { (<16 ye }\end{array}$ & years) \\
\hline 1. Infantile $\mathrm{X}$-linked agammaglobulinemia & 70 & 0 & 70 & $0 s$ & Suspicious 19 \\
\hline 2. Thymic hypoplasia (DiGeorge syndrome) & 26 & 10 & 36 & 01 & DiGeorge syndrome 27 \\
\hline 3. Severe combined imimunodeficiency & 43 & 15 & 58 & 0 & Suspicious $8, \mathrm{ADA}(-) 2$ \\
\hline 4. Selective IgA deficiency & 45 & 37 & 82 & 211 & Under 1 year 7 \\
\hline 5. Selective Ig deficiency other than IgA & 10 & 0 & 10 & 11 & $\operatorname{IgM}(-) 7$ \\
\hline 6. Immunodeficiency with ataxia-telangiectasia & 28 & 23 & 51 & 1 & \\
\hline 7. Immunodeficiency with thrombocytopenia and eczema & 44 & (1) & 45 & 0 & \\
\hline $\begin{array}{l}\text { 8. Immunodeficiency with normal or } \\
\text { hypergammaglobulinemia }\end{array}$ & 14 & 3 & 17 & 21 & Hyper IgM 12 \\
\hline 9. Transient hypogammaglobulinemia of infancy & 26 & 11 & 37 & 0 & \\
\hline 10. Immunodeficiency with thymoma & 5 & 4 & 9 & 9 & \\
\hline 11. Common variable immunodeficiency & 66 & 37 & 103 & 20 & \\
\hline 12. Chronic mucocutaneous candidiasis & 4 & 7 & 11 & 1 & \\
\hline 13. Immunodeficiency with short-limbed dwarfism & 0 & 2 & 2 & 0 & \\
\hline 14. Chronic granulomatous disease & 75 & 13 & 88 & 3 & \\
\hline 15. Chediak-Higashi disease & 4 & 4 & 8 & 0 & \\
\hline 16. Other neutrophil dysfunction syndromes & 22 & 16 & 38 & 01 & Hyper IgE 25 \\
\hline 17. Complement deficiency & 4 & 9 & 13 & 7 & \\
\hline 18. Others & 3 & 2 & 5 & 1 & \\
\hline Total & $\begin{array}{c}.489 \\
(71.6 \%)\end{array}$ & $\begin{array}{c}194 \\
(28.4 \%)\end{array}$ & 683 & $\begin{array}{c}66 \\
(9.7 \%)\end{array}$ & \\
\hline
\end{tabular}


表 2 Reported neoplasmas in the registered patients with primary immunodeficiency diseases

\begin{tabular}{|c|c|c|c|c|c|c|c|}
\hline Case & No. & Age/Sex & Immunodeficiency & Neoplasmas & $\begin{array}{c}\text { Patient's status } \\
\text { (Cause) }\end{array}$ & $\begin{array}{l}\text { Age of } \\
\text { death }\end{array}$ & Autopsy \\
\hline 1) & 22 & $0 \mathrm{Y} / \mathrm{M}$ & Chediak-Higashi & Malig. lymphoma & D(Malig. lymphoma) & $3 \mathrm{M}$ & No \\
\hline 2) & 23 & $1 \mathrm{Y} / \mathrm{M}$ & Chediak-Higashi & Malig. lymphoma & D(Malig. lymphoma) & $1 \mathrm{Y} 3 \mathrm{M}$ & No \\
\hline 3) & 28 & $3 \mathrm{Y} / \mathrm{M}$ & Transient hypogamma. & Acute leukemia (ALL) & $\mathrm{D}$ & $3 \mathrm{Y}$ & Yes \\
\hline 4) & 79 & $6 \mathrm{Y} / \mathrm{M}$ & A.T. & Malig. lymphoma (NHL) & D (Malig. lymphoma) & $11 \mathrm{Y}$ & $?$ \\
\hline 5) & 156 & $1 \mathrm{Y} / \mathrm{M}$ & I.D. with hyper-IgM & Brain tumor & D & $?$ & No \\
\hline 6) & 195 & $10 \mathrm{Y} / \mathrm{M}$ & A.T. & $\begin{array}{l}\text { Renal cell Ca. }+ \\
\text { Hepatoma }\end{array}$ & $\mathrm{D}(\mathrm{Ca})$. & $22 \mathrm{Y}$ & Yes \\
\hline 7) & 208 & $5 \mathrm{Y} / \mathrm{M}$ & IgA def. & Hodgkin & $\mathrm{D}($ Hodgkin $)$ & $9 \mathrm{Y}$ & Yes \\
\hline 8) & 240 & $12 \mathrm{Y} / \mathrm{M}$ & W.A. & Malig. lymphoma & D (Malig. lymphoma) & $14 \mathrm{Y}$ & No \\
\hline 9) & 279 & $9 \mathrm{Y} / \mathrm{M}$ & A.T. & Gastric Ca. & D(Gastric Ca.) & $14 \mathrm{Y}$ & Yes \\
\hline 10) & 289 & $13 \mathrm{Y} / \mathrm{F}$ & C.V.I.D. & Malig. lymphoma (NHL) & $\mathrm{D}$ (Pneumonia) & $22 \mathrm{Y}$ & Yes \\
\hline 11) & 365 & $0 \mathrm{Y} / \mathrm{M}$ & Chediak-Higashi & Lymphosarcoma & D(Lymphosarcoma) & $6 \mathrm{M}$ & Yes \\
\hline ?12) & 1016 & $7 \mathrm{M} / \mathrm{M}$ & S.C.I.D. & Lymphoma of liver & $D($ Pneumonia $)$ & $1 \mathrm{Y}$ & Yes \\
\hline 13) & 1085 & $1 \mathrm{Y} / \mathrm{M}$ & IgA def. & Glioma & D (Glioma $)$ & $1 \mathrm{Y} 5 \mathrm{M}$ & Yes \\
\hline 14) & 1141 & $9 \mathrm{Y} / \mathrm{M}$ & A.T. & Hepatoma & $\mathrm{D}$ (Hepatoma) & $17 \mathrm{Y}$ & Yes \\
\hline 15) & 1192 & $6 \mathrm{Y} / \mathrm{M}$ & A.T. & Acute leukemia (ALL) & $D$ (Pneumonia) & $8 \mathrm{Y}$ & No \\
\hline$? 16)$ & 1207 & $5^{\prime} \mathbf{M} / \mathbf{M}$ & Hyper IgE syndr. & Lymphoma? & $\begin{array}{c}\mathrm{D} \text { (Intracranial } \\
\text { hemorrhage) }\end{array}$ & $11 \mathrm{M}$ & No \\
\hline 17) & 1244 & $1 \mathrm{Y} / \mathrm{M}$ & A.T. & Acute leukemia (ALL) & A & & \\
\hline 18) & 1294 & $5 \mathrm{Y} / \mathrm{M}$ & C.V.I.D. & Malig lymphoma(NHL) & D(Malig. lymphoma) & $8 Y$ & No \\
\hline 19) & 1301 & $6 \mathrm{Y} / \mathrm{M}$ & A.T. & Malig lymphoma(NHL) & D(Malig. lymphoma) & $15 \mathrm{Y}$ & Yes \\
\hline (20) & 234 & $59 \mathrm{Y} / \mathrm{M}$ & C.V.I.D. & Gastric Ca. & A & & \\
\hline (O21) & 1250 & $52 \mathrm{Y} / \mathrm{M}$ & IgA def. & Cholangio $\mathrm{Ca}$. & $\overrightarrow{\mathrm{D}}(\mathrm{Ca})$. & $52 \mathrm{Y}$ & Yes \\
\hline (O22) & 1324 & $18 \mathrm{Y} / \mathrm{M}$ & C.V.I.D. & Gastric Ca. & $\mathrm{D}(\mathrm{Ca})$. & $22 \mathrm{Y}$ & Yes \\
\hline
\end{tabular}

?: Doubtful 'malignant' tumor. (O):Adult cases at diagnosis of I.D. A : Alive D: Dead

表 3 Reported malignancies (confirmed) in the registered patients with primary immunodeficiency diseases

\begin{tabular}{|c|c|c|c|}
\hline Disease & $\begin{array}{l}\text { Total } \\
\text { case }\end{array}$ & $\begin{array}{l}\text { Pt. with } \\
\text { malignancy }\end{array}$ & Malignancy \\
\hline Selective IgA deficiency & 82 & $3(3.7 \%)$ & Hodgkin 1 Glioma 1 Cholangioma 1 \\
\hline Ataxia telangiectasia & 51 & $7(13.7 \%)$ & $\begin{array}{l}\text { NHL } 2 \text { ALL } 2 \text { Gastric Ca } 1 \\
\text { Renal cell } \mathrm{Ca}+\text { Hepatoma } 1 \\
\text { Hepatoma } 1\end{array}$ \\
\hline Wiskott-Aldrich syndrome & 45 & $1(2.2 \%)$ & Malig. Lymphoma 1 \\
\hline Immunodeficiency with hyper-IgM & 12 & $1(8.3 \%)$ & Brain tumor 1 \\
\hline Transient hypogammaglobulinemia of infancy & 37 & $1(2.7 \%)$ & ALL 1 \\
\hline Common variable immunodeficiency & 103 & $4(3.9 \%)$ & NHL 2 Gastric $\mathrm{Ca} 2$ \\
\hline ? Chediak-Higashi syndrome & 8 & $3(37.5 \%)$ & Malig. Lymphoma? 3 \\
\hline
\end{tabular}

(May 1985)

した 2 例は悪性腫瘍であることが疑わしいとされている のでこれを除くと 20 例となり，全症例の $2.9 \%$ に相当 する.また， 3 例は初診時成人例であるので, 初診時小 児の例は 17 例となる。

こ机を，免疫不全症候群の疾患別にまとめると表 3 の ごとくになる.

もっとも頻度の高い疾患は Chediak-Higashi 症候群で，
8 例中 3 例に悪性リンパ腫様変化が認められ, $37.5 \%$ に 及んだ. 本症例群における急性増悪は悪性変化であるか 否かが問題の例もあるとされるが1)，特殊な例として注 目されよう。

次に頻度の高い疾患は Ataxia-telangiectasia であり， 51 例中 7 例 (13.7\%)にこれを認めた。これについては 後述する. 
表 4 Primary immunodeficiency diseases and malignancies

\begin{tabular}{|c|c|c|c|c|c|c|}
\hline \multirow[b]{2}{*}{ Immunodeficiency } & \multicolumn{3}{|c|}{ Japan (May 1985) } & \multicolumn{3}{|c|}{ ICR (1978) } \\
\hline & $\begin{array}{l}\text { Number of } \\
\text { patients }\end{array}$ & $\begin{array}{l}\text { With } \\
\text { malignancy }\end{array}$ & $\%$ & $\begin{array}{l}\text { Number of } \\
\text { patients }\end{array}$ & $\begin{array}{l}\text { With } \\
\text { malignancy }\end{array}$ & $\%$ \\
\hline Ataxia-telangicetasia & 51 & 7 & 13.7 & 283 & 33 & 11.7 \\
\hline Selective IgA deficiency & 82 & 3 & 3.7 & 833 & 20 & 2.4 \\
\hline Wiskott-Aldrich syndrome & 45 & 1 & 2.2 & 136 & 21 & 15.4 \\
\hline $\begin{array}{l}\text { Transient hypogamma- } \\
\text { globulinemia of infancy }\end{array}$ & 37 & 1. & 2.6 & 537 & 0 & 0 \\
\hline $\begin{array}{l}\text { Immunodeficiency with } \\
\text { hyper-IgM-emia }\end{array}$ & 12 & 1 & 8.3 & 65 & 1 & 1.5 \\
\hline $\begin{array}{l}\text { Common variable } \\
\text { immunodeficiency }\end{array}$ & 103 & 4 & 3.9 & 626 & 27 & 4.3 \\
\hline Total (Children) & 617 & 14 & 2.3 & & & \\
\hline Total (1) & 518 & 17 & 3.3 & 3,356 & 134 & 4.0 \\
\hline
\end{tabular}

* 1 : Restricted types of immunodeficiency same to ICR's report.

表 5 Distribution of malignancies by age and sex in AT patients collected by the ICR (1982) and JIR (1985)

\begin{tabular}{|c|c|c|c|c|c|c|c|c|c|c|c|}
\hline \multirow[b]{3}{*}{$\begin{array}{l}\text { Non-Hodgkin } \\
\text { lymphoma }\end{array}$} & \multirow{2}{*}{\multicolumn{2}{|c|}{ Total }} & \multicolumn{5}{|c|}{ Males } & \multicolumn{3}{|c|}{ Females } & \multirow{3}{*}{$\begin{array}{c}\mathrm{M} / \mathrm{F} \\
1.51\end{array}$} \\
\hline & & & \multicolumn{2}{|c|}{$0-15 Y$} & \multicolumn{2}{|c|}{$16 \mathrm{Y}-$} & \multirow{2}{*}{$\frac{\text { Total }}{30}$} & \multirow{2}{*}{$\frac{0-15 Y}{18}$} & \multirow{2}{*}{$\frac{16 Y-}{0}$} & \multirow{2}{*}{$\frac{\text { Total }}{18}$} & \\
\hline & $\begin{array}{c}48 \\
(44 \%)\end{array}$ & $\begin{array}{l}{[2]} \\
(29 \%)\end{array}$ & 25 & [2] & 5 & & & & & & \\
\hline Leukemia & $\begin{array}{c}26 \\
(24 \%)\end{array}$ & $\begin{array}{l}(2) \\
(29 \%)\end{array}$ & 15 & [2] & 1 & & 16 & 7 & 3 & 10 & 1.41 \\
\hline $\begin{array}{l}\text { Hodgkin } \\
\text { disease }\end{array}$ & $\begin{array}{c}12 \\
(11 \%)\end{array}$ & $\begin{array}{l}{[0]} \\
(0 \%)\end{array}$ & 7 & & 0 & & 7 & 3 & 2 & 5 & 1.40 \\
\hline Carcinoma & $\begin{array}{c}22 \\
(20 \%)\end{array}$ & $\begin{array}{l}{[3]} \\
(43 \%)\end{array}$ & 2 & $(1)$ & 3 & (2) & 5 & 4 & 13 & 17 & 0.27 \\
\hline Total & $\begin{array}{c}108 \\
(100 \%)\end{array}$ & $\begin{array}{l}(7] \\
(100 \%)\end{array}$ & $\begin{array}{c}49 \\
(84 \%)\end{array}$ & $\begin{array}{l}{[5]} \\
(71 \%)\end{array}$ & $\begin{array}{c}9 \\
\left(16^{\circ} \circ\right)\end{array}$ & $\begin{array}{l}{[2]} \\
\left(29^{\circ} 0\right)\end{array}$ & 58 & $\begin{array}{c}32 \\
(64 \%)\end{array}$ & $\begin{array}{c}18 \\
(36 \%)\end{array}$ & 50 & \\
\hline
\end{tabular}

[ ] : JIR May 1985

このほか, Common variable immunodeficiency, 選 択的 IgA 欠損症等にも合併例が認められた.

Wiskott-Aldrich 症候群では 45 例中 1 例に悪性リンパ 腫が認められたのみであった。

この成績を，米国ミネンタ大学で行われている世界各 地からの同様の症例の統計である ICR の成績 ${ }^{2)}$ と比較し た表が表 4 である.

表でみるように，今回の成績の傾向は，ICR のものと 類似であるが, Wiskott-Aldrich 症候群のみは $15.4 \%$ と 高い合併頻度が報告されている点わが国の集計と異なっ ている. 全体では 3,336 例中 134 例 (4.0\%)の合併例が みられたといい，わが国の症例から ICR が対象としてい
ない疾患を除いた場合の頻度 518 例中 17 例 (3.3\%) に 近い值である.

わが国の集計，ICR ${ }^{3)}$ を通じて，Ataxia-telangiectasia

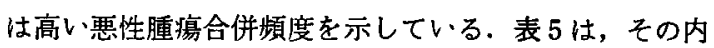
訳を示す。

小児例は ICR では 81 例中 43 例 $(53 \%)$ が NonHodgkin lymphoma で, 癌は6 例 (7\%) のみであるが， 成人では癌が 16 例 $(59.3 \%)$ と反対に多数を占め，こと に女性では $72 \%$ が癌であった，癌としては，胃癌, 腎 㿋, 卵巣癌, 肝癌などの報告が多い。かが国の例は少数 であるが, 男性に限られ, 澏が多いように思われた。 


\section{II. ま とめ}

原発性免疫不全症候群に合併する悪性腫瘍について, わが国の症例登録についてまとめ, ICR の成績と比較し 報告した。

わが国の原発性免疫不全症候群の登録症例の約 $3 \%$ に 悪性腫湯の報告があり，小児例についてみると，一般健 康小児の約 500 倍の発生率であると考えられた。

免疫不全症候群の中では, Chediak-Higashi 症候群, Ataxia-telangiectasia でことに頻度が高く，そのほかー 般に ICR の結果と同様の傾向があるが, Wiskott-Aldrich 症候群の悪性腫瘍合併症例は少なかった. X-linked lymphoproliferative disease はまだ確実な報告が見当たら なかった。

悪性腫瘍としては, Non-Hodgkin lymphoma をはし めとする悪性リンパ腫, 白血病等がもっとも多く， Ataxia-telangiectasia では癌もしばしば認められた.

なお，わが国の症例には，同胞がいずれも免疫不全症 候群と悪性腫瘍を発生した例は Chediak-Higashi 症候群 に1組みられたのみであり，重複して原発性悪性腫瘍を 認めたものは Ataxia-telangiectasia の1例のみであっ た.
終わりに，本調查に協力された全国各位に媣謝するし だいである.

\section{文献}

1) Krueger, G.R.F., et al. : Lymphoreticular tissue lesions in Steinbrinck-Chediak-Higashi syndrome. Virchows Arch. Abt. A. Path. Anat., 353 : 273, 1971.

2) Spector, B.D., et al : Genetically determined immunodeficiency diseases (GDID) and malignancy : Report from the ImmunodeficiencyCancer Registry. Clin. Immunol. Immunopathol., $11: 12,1978$.

3) Spector, B.D., et al. : Epidemiology of cancer in ataxia-telangiectasia. Ataxia-telangiectasia-A cellular and molecular link between cancer, neuropathology and immune deficiency. Bridges, B.A. and Harnden, D.G. eds. John Wiley \& Sons Ltd. Chichester, 1982, pp. 105. 